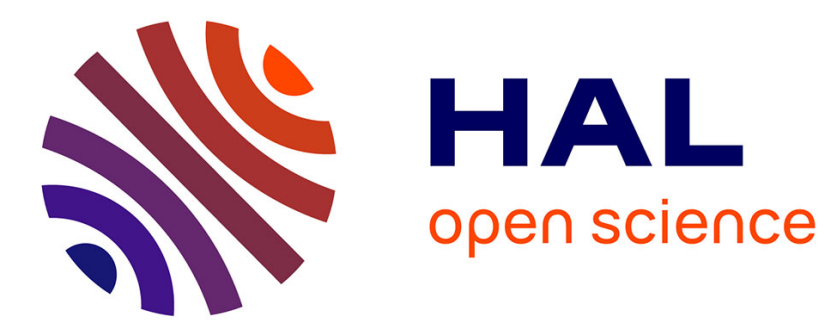

\title{
The European Union Emissions Trading Scheme: should we throw the flagship out with the bathwater?
}

Frédéric Branger, Oskar Lecuyer, Philippe Quirion

\section{To cite this version:}

Frédéric Branger, Oskar Lecuyer, Philippe Quirion. The European Union Emissions Trading Scheme: should we throw the flagship out with the bathwater?. Wiley Interdisciplinary Reviews: Climate Change, 2015, 6 (1), pp.9-16. 10.1002/wcc.326 . hal-01137875

\section{HAL Id: hal-01137875 https://hal.science/hal-01137875}

Submitted on 31 Mar 2015

HAL is a multi-disciplinary open access archive for the deposit and dissemination of scientific research documents, whether they are published or not. The documents may come from teaching and research institutions in France or abroad, or from public or private research centers.
L'archive ouverte pluridisciplinaire HAL, est destinée au dépôt et à la diffusion de documents scientifiques de niveau recherche, publiés ou non, émanant des établissements d'enseignement et de recherche français ou étrangers, des laboratoires publics ou privés. 


\title{
WIREs CLIMATE CHANGE
}

\author{
Article type: Opinion
}

The European Union Emissions Trading Scheme: should we throw the flagship out with the bathwater?

\author{
Frédéric Branger, CIRED \\ branger@centre-cired.fr \\ Oskar Lecuyer, CIRED \\ lecuyer@centre-cired.fr \\ Philippe Quirion, CNRS, CIRED \\ quirion@centre-cired.fr \\ corresponding author
}

\section{Abstract}

The European Union Emissions Trading System (EU ETS), presented as the "flagship" of European climate policy, is subject to many criticisms from different stakeholders: it does not reduce carbon emissions nor generate enough low-carbon innovation, it induces competitiveness losses and carbon leakage, its distributional effects are unfair and finally, it is susceptible to fraud. We review these criticisms and recognize that: abatement is real (though small), innovation is insufficient, competitiveness losses and carbon leakage did not seem to take place, distributional effects have indeed been unfair and fraud has been important. Some of these problems could have been avoided. They can still be corrected by reforming the ETS through the introduction of price limits and by developing complementary policies, both because the ETS reform may fail and because the ETS cannot address all the relevant market failures. 
Presented as Europe's flagship policy to tackle climate change, the European Emissions Trading System (EU ETS) is on the brink of capsizing. The price of its Emission Allowance (EUA) has been around $€ 5$ since 2013 , compared to more than $€ 25$ in July 2008. Since its implementation in 2008, heavy industries blame the EU-ETS on being a threat to competitiveness. Some green Non-Governmental Organizations (NGOs) accuse it of commoditizing the environment and of being inefficient at reducing carbon emissions, and even propose its abolition ${ }^{1}$. Several cases of fraud have made headlines. Finally, the billions of euros earned by private electricity companies at the expense of consumers makes its distributional effects highly unfair to many.

However, the adoption of this policy by the EU seemed at first to align with the recommendations of most economists, who argue that command-and-control regulation is not cost-effective and should be replaced by taxation or emissions trading systems ${ }^{2}$. For this purpose, in 2005, the European Association of Environmental and Resource Economists gave its first award of European Practitioner Achievement in Applying Environmental Economics to Jos Delbeke, the Director General of the Directorate-General for Climate Action in the European Commission, for his active role in the implementation of the EU ETS. Why this paradox? Were the economists' recommendations unwise? Are the criticisms unfounded? Should the EU ETS be amended or abandoned?

Our diagnostic is that a major part of these problems are real but could have been avoided - and can still be corrected - not by ignoring the works of economists but by analyzing them more closely. The flagship can still be refloated if Member States gather enough political will and if the Commission abandons its ideological opposition to the control of carbon price. But the EU ETS should not be used as an argument to repeal the other climate policy instruments in Europe. The outline of this article is as follows; we review the main criticisms the EU ETS has faced, i.e. no emissions reduction (1), competitiveness losses and carbon leakage (2), unfair distributional effects (3) and fraud (4), and end with some policy recommendations.

\section{Is the EU ETS efficient at reducing emissions?}

Emissions reductions attributable to the EU ETS are the difference between actual emissions and hypothetical emissions that would have occurred without the scheme. Assessing abatement brought by the EU ETS is thus a thorny exercise and necessitates a counterfactual emissions scenario.

Contrary to what one could expect, the literature on the subject (reviewed by Laing et al. ${ }^{3}$ ) is narrow: three peer-reviewed studies ${ }^{4-6}$, two working papers ${ }^{7,8}$ and a couple of reports from finance institutions. They come to the conclusion that emission savings are "in the range 40-80 MtCO2 per year, about 2-4\% of total capped emissions". However, this result holds only for the pre-crisis period (2005-2008). Evidence or non-evidence of abatement brought by the EU ETS is missing after 2009, a period marked by an exceptional economic recession that makes the elaboration of a counterfactual scenario difficult.

In addition, for many the EU ETS aims not only at achieving least-cost short-term emission reductions (for example fuel-switching or operational energy efficiency ${ }^{9}$ ), but also to 
encourage innovation and long-term investments in low-carbon technologies. The literature ${ }^{3}$, mostly based on managerial surveys, suggests that the EU ETS affected investment decisions but in a very limited way, far from what is necessary to achieve longterm targets the EU has set out.

Furthermore, during phase II, roughly one billion offset credits were surrendered ${ }^{10}$, mostly Certified Emission Reduction (CERs) credits from the Clean Development Mechanism (CDM), corresponding to $10 \%$ of the cap. They increased the global surplus of allowances created by the economic recession. This in turn reduced abatement through two channels: a price effect (the EUA price decreased due to the surplus) and possibly an initial allocation effect (Zachman et al. $^{7}$ find that a larger initial allocation may discourage abatement, contradicting the "independence property" of emissions trading ${ }^{11}$ ). Furthermore, some projects were non-additional, and the abatement induced by a part of the others was most probably overestimated $^{12}$, though the exact quantification of this overestimation is contentious ${ }^{13}$.

Had these credits not been allowed, less abatement would have occurred outside the EU territory, but more abatement would have occurred within. The massive allowances surplus and the low carbon price issues would then be less serious and be less a threat to the effectiveness and credibility of the EU ETS. Realizing this, the Commission partly corrected the situation for the third phase by banning offset credits coming from industrial gases, imposing that offset credits come from least developed countries, and setting a smaller amount of authorized offset credits. It can be noted that nothing forced the European Union to acknowledge offsetting in the EU ETS. This excessive enthusiasm towards flexibility mechanisms is now paid by a decreased environmental efficiency.

\section{Carbon leakage and loss of competitiveness: what is the reality?}

European institutions unilaterally introduced the EU ETS in 2005, preparing a hypothetical global carbon price implementation. This explains why the EU ETS faced such strong opposition from heavy industries, threatening for carbon leakage and loss of competitiveness. They argue that the EU ETS induces a comparative disadvantage for European firms manufacturing carbon-intensive products, because the EUA price increases production costs. The production of carbon-intensive sector migrates to "carbon havens"14, leading to job destruction, relocation and profit losses. In addition to those losses, relocating production potentially creates a "carbon leakage" and cancels out the environmental benefits of the policy. Emissions reductions in Europe would be compensated by increased emissions in the rest of the world.

The sectors at risk are those having high carbon costs (directly or indirectly through increased electricity prices) and facing important international competition ${ }^{22}$. The Commission classified 146 sectors (out of 256 in the EU ETS) as "deemed to be exposed at risk of carbon leakage", and granted them 100\% free allocation in phase III (2013-2020). They include cement, steel, aluminum, oil refining, ceramics, pulp and paper and some chemicals, and represent $77 \%{ }^{23}$ of industrial emissions. 
The numerous ex ante studies have estimated a carbon leakage ratio ${ }^{a}$ in a range of $5-25 \%$ 15,16 , depending on policy scenarios and model parameters. Ex post econometric studies have not revealed statistically significant effects ${ }^{17-21}$. However the industries have benefitted so far from protection, including: free allocations (though as allocations bear an opportunity cost, the ability of free allocation to prevent operational leakage is questionable), low carbon price and long term electricity contracts for aluminum producers. Further, long-term effects like the evolution of production capacities have not yet been studied statistically.

The debate has essentially focused on negative aspects of unilateral climate policies, but positive phenomena can be highlighted as well: climate (and policy) spillovers ${ }^{24,25}$ counteract carbon leakage, Porter effects ${ }^{26}$ and first mover advantage counterbalance potential competitiveness losses ${ }^{14}$.

Contrary to what was expected, EITE (for Energy Intensive Trade Exposed) sectors have directly thrived from the scheme. The economic downturn led to a substantial fall in production which in turn generated a substantial surplus of allowances, as caps were determined on pre-crisis production expectations. For the cement sector alone, these "overallocation profits" are estimated at $€ 3.5$ billion ${ }^{27}$. EITE sectors have suffered from the crisis through reduced sales and low margins, but their financial situation would have been worse had the EU ETS not existed. Presented as a threat to competitiveness, the EU ETS has actually improved competitiveness, when defined as ability to earn ${ }^{28}$.

Admittedly, the allocation methodology has improved significantly between phase II and phase III. The centralized approach based on stringent sectorial benchmarks has reduced distortions among installations and decreased the cap for the manufacturing sectors by $20 \%{ }^{29}$. This cap will decrease even further in the future by a factor of $1.74 \%$ per year (though this rate of tightening is not nearly fast enough over the long term to keep within the $2^{\circ} \mathrm{C}$ limit). But there is still room for criticism. First, for the elaboration of the "carbon leakage list", carbon costs are assessed based on a carbon price of 30 euros, whereas it has been at less than 8 euros since the beginning of phase III and should remain low because of the structural excess of allowances ${ }^{30}$ except if an ambitious reform takes place in the next years. Second, allocations caps are mostly based on pre-crisis levels of productions, significantly higher than what is expected in the nearest future. The majority of companies are then likely to keep benefiting from an excess of allowances.

\section{Unfair distributional effects?}

In 2006, many observers were shocked by the publication of studies ${ }^{31}$ revealing that electricity companies passed along the price of their allowances to their consumers ${ }^{32}$. However, it is a logical behavior that was forecasted by economists well before the beginning of the EU ETS ${ }^{33,34}$. Even distributed free of charge, allowances can be sold. Therefore, they carry an opportunity cost that electricity companies pass along in unregulated electricity markets. This price rise is desirable in a way because it gives incentives to reduce electricity consumption, which is an efficient option to reduce carbon 
emissions. However, it is questionable that the scarcity rent created by free allocation benefits electricity companies, which are private to a large extent, instead of all citizens.

The ability of electricity producers to pass through the carbon price was confirmed by numerous additional studies listed in Laing et al. $^{3}$. The reactions provoked by these windfall profits (that were assessed at 35 billion euros for phases I and II according to Lise et al. ${ }^{35}$, an ex ante estimation admittedly based on $\mathrm{CO}_{2}$ prices higher than those effectively encountered) made a solid case for the Commission to obtain full auctioning of allowances for electricity companies in phase III. Even if windfall profits were probably not totally unintended if we consider that free allocation was implemented as a necessary concession to launch the EU ETS, it is unfortunate that they were maintained until the end of phase II, eight years after the beginning of the scheme.

Ability to pass-through the allowance price to the consumer has been demonstrated outside of the electricity sector as well ${ }^{36-38}$. However the evidence is much scarcer than in the electricity sector, and would gain to be expanded as, beyond distributional effects, it is an indirect measure of the exposure to carbon leakage. Thus, depending on the pass-through rate and the amount of free allocation, some industrial sectors have also benefitted from windfall profits, which they will possibly maintain as they will continue to receive free allowances at least until 2020. However for the industry sector, overallocation profits (cf. previous section) are likely to be bigger in magnitude than windfall profits.

\section{The EU ETS: a bargain for fraudsters?}

Frauds hit the headlines and gave a disastrous image of the EU ETS, a policy instrument that is poorly known and understood by the general public. Two types of frauds altered the environmental integrity of the EU ETS: the recycling of CERs and the selling of nonadditional offset credits. Other frauds (such as Value-Added Tax frauds) affected the economic efficiency of the market, because of price distortions caused by momentary carbon exchange closures and decrease in market confidence. More importantly, VAT frauds alone caused an estimated worth of 5 billion euros in lost tax revenues between 2009 and 2010, according to Europol ${ }^{39}$.

The recycling of CERs resulted from a regulatory loophole. Until 2010, nothing banned CERs used by national installations for their own compliance to be resold by countries on the international market of the Kyoto Protocol. In this way the Hungarian government legally sold 800000 CERs surrendered by Hungarian companies to a trading company based in Hong Kong, on the understanding that they would be sold to Japan ${ }^{b}$, and informed the European Commission of the transaction ${ }^{c}$. However some of these credits found their way back in the EU ETS exchange platform BlueNext. After a trading halt, authorities managed to isolate the recycled CERs ${ }^{\text {. }}$.

The European Commission acted repeatedly to correct and prevent these frauds. In March 2010, in order to prevent VAT fraud, it adopted a directive changing the way the VAT was perceived on carbon emissions allowances (the reverse charge mechanism). One month later, in order to prevent CER recycling, registers regulation were modified (CERs are now 
blocked on "withdrawal accounts" after their use for compliance by market operators). In 2012 , the 30 national carbon registries were replaced by a single platform supposed to match the security standards of the financial sector. Yet Interpol ${ }^{40}$ urges for a careful enforcement of the reforms and warns against possible ongoing frauds. The relative immaturity of the market and the intangible nature of allowances make carbon markets particularly vulnerable compared to other markets.

\section{Recommendations: try to refloat the flagship, but maintain the rest of the fleet as well}

After reviewing of the criticisms addressed to the EU ETS, we conclude that at least some of them are valid. The ETS was plagued twice by allowance overallocation during its short history. Windfall profits generated unfair distributional effects. Careless market rules allowed massive fraud. Allowance allocation was massively distorted among Member States in the first two phases. The ETS does not seem to have generated significant innovation in GHG abatement technologies. Yet, we do not think that the flagship should be scuttled.

First, the limited number of existing studies indicates that the ETS has reduced emissions by 40 to $80 \mathrm{Mt}$ per year during the first phase, when the carbon price was significant, an important figure compared to other existing climate policies. Given the available evidence, this result was reached without generating leakage or competitiveness problems.

Second, no alternative policy with such a large scope is available in the foreseeable future. A carbon tax would be far preferable: in the case of climate change mitigation, all studies since Pizer ${ }^{41}$ have indicated the superiority of a price instrument over a quantity instrument. However, the reasons that led to the failure of the European carbon tax in the early 1990s remain, in particular the unanimity rule for fiscal decisions ${ }^{f}$.

Third, some of the problems caused by the EU ETS (in particular, the unfair distributional effects due to the allowances allocation rules) may have been the necessary price, initially at least, to avoid the industry sinking the ETS in the same way it did the carbon tax ${ }^{42}$.

Fourth, the reforms applied from 2013 onwards correct some of the early problems, especially the windfall profits in the power sector and the distortions in allowance allocation among Member States.

Refloating the flagship implies first to admit that the strong fluctuations of the carbon price are not incidental. Quite the contrary, they are inevitable because the supply of allowances is rigid, whereas the demand, whose short-term price-elasticity is low, oscillates according to the economic context and the implementation of other climate and energy policies. Consequently, with a pure quantity instrument, it is impossible to prevent both the risk of allowance price collapse (like in 2007 or currently) and symmetrically the risk of an excessive allowance price that would lead to a fierce reaction of heavy industries in the name of carbon leakage and loss of competitiveness. 
Because of uncertainty combined to the flatness of the marginal benefits curve and to the steepness of the marginal abatement cost curve, a pure quantity instrument, like the EU ETS, with an unregulated price, constitutes a very imperfect policy compared to a carbon $\operatorname{tax}^{41}$. As shown in Lecuyer and Quirion ${ }^{43}$, in most emission trading systems so far, there have been periods in which the allowance price has dropped to zero or to the price floor (when the latter exists), indicating a non-binding cap. As Wolfgang Sterk puts it ${ }^{f}$, "Hot air isn't a sad aberration; it's a feature of quantity-based climate commitments".

Admittedly, a carbon tax is out of reach of the EU, but it is possible to reform the ETS in this direction: all it takes is to set a price floor during the auctioning of allowances (and possibly a price ceiling, although price spikes are less likely than price drops). Unfortunately, the European Commission ${ }^{44}$ is extremely reluctant to take this option because of arguments that are largely ideological ${ }^{g}$. The solution proposed by the Commission, a market stability reserve which would automatically adjust the supply of allowances, is unable to solve the problem $^{45}$, and could even aggravate allowance price instability ${ }^{46,47}$. Moreover there is currently no indication that a majority of Member States would favor this reform.

Hence, although the flagship can be refloated, we cannot be sure that it will be, and this uncertainty must be taken into account when deciding whether the EU should keep other climate-energy policies and targets, beyond its GHG emissions target and the EU ETS. Unfortunately, most discussions on this topic take for granted that the EU ETS cap will be effective in the next years ${ }^{48}$. In particular, many researchers conclude that renewable energy targets and policies should be scrapped because of the following argument: since $\mathrm{CO}_{2}$ emissions are capped by the ETS, more solar and wind electricity generation will not abate them but will only reduce the $\mathrm{CO}_{2}$ price, in turn favoring coal generation instead of gas (the "green serves the dirtiest" argument ${ }^{49, \mathrm{~h}}$ ). The same argument can be applied against electricity saving policies. Yet, allowing the possibility that the cap may not be effective suffices to invalidate the argument and to justify the existence of such complementary policies ${ }^{43}$.

Moreover, the existence of multiple failures in the allowance and related markets prevents the EU ETS alone from giving the right incentives for an efficient long-term reduction of GHG emissions and justify complementary policies. Innovation spillovers are a classic example $e^{50,51}$. The carbon price fails to induce a sufficient level of innovation because of the spillovers the latter generates, justifying an additional support for green innovation ${ }^{52,53}$. Other failures of e.g. energy and housing market also lead to inefficient resource allocations: final consumers often ignore the energy consumption of their dwelling or appliances (information failure ${ }^{54}$ ), and split incentives often lead to inefficiently low energy efficiency investment in buildings ${ }^{55}$. Thus, energy efficiency labels and standards can correct these market failures and then improve economic efficiency, even though emissions are capped by the EU ETS ${ }^{56}$.

Finally, in many sectors, reaching ambitious long-term mitigation targets requires investing in costly long-lived green capital. The slow diffusion of such technologies, along with their differentiated mitigation potential, justifies the setting of clear separated sectorial targets ${ }^{57}$. Moreover, future electricity and carbon prices cannot be fully anticipated which introduces a bias against investment in carbon-free technologies, leading to a suboptimal investment 
schedule $^{58}$. Therefore, clear transition trajectories in key sectors such as electricity generation, housing and transportation would go a long way towards achieving their full potential.

To sum up, a robust strategy to save the European climate policy should combine an attempt to reform of the ETS through the introduction of a price floor (and possibly a price ceiling), and the development of complementary policies, even in the electricity sector whose emissions are covered by the ETS, both because the ETS reform may fail and because the ETS cannot address all the relevant market failures. Fortunately, most GHG cap-andtrade systems implemented or planned worldwide seem to have benefited from the European experience. In particular, the California and Quebec ETS include an auction price floor at $10 \$ /$ ton in 2012 rising at 5\% per year plus inflation adjustment and some Chinese pilots ETS (Shenzhen, Guangdong and Hubei) have set aside reserve allowances to manage price fluctuations. Moreover, the planned Korean ETS features allowances reserve to contain price and so does the ETS in California and Quebec. Interestingly, following the implementation of these systems, these countries and regions have kept the pre-existing climate policy instruments, although whether they did it because of a possible failure of the ETS and/or because these instruments are supposed to address other market failures remain an open question.

\section{Notes}

${ }^{a}$ The leakage ratio is defined as the increase of emissions in the rest of the world in proportion to the decrease of emissions in the climate coalition. A 50\% leakage ratio does not mean that $50 \%$ of the emissions have leaked but that $50 \%$ of emissions reductions are undermined by emissions increase outside the coalition. Below a leakage ratio of $100 \%$, the policy is environmentally beneficial.

\footnotetext{
${ }^{b}$ www.lexology.com/library/detail.aspx?g=47ca7d94-22e5-4056-8849-5bd8081d2290

${ }^{c}$ http://www.bloomberg.com/news/2010-04-14/bluenext-arranges-swap-backs-of-recycledco2-credits-after-trading-halt.html
}

${ }^{d}$ http://www.bloomberg.com/news/2010-04-14/bluenext-arranges-swap-backs-ofrecycled-co2-credits-after-trading-halt.html

${ }^{\mathrm{e}}$ All heads of state of the 28 Member States forming the European Council would need to agree for a carbon tax. On the contrary cap-and-trade implementation and modifications are not considered as fiscal decisions, and necessitate only the qualified majority of two thirds in the European parliament to be passed. 
${ }^{f}$ http://scrapbookofaclimatehawk.wordpress.com/2013/07/02/hot-air-isnt-a-sadaberration-its-a-feature-of-quantity-based-climate-commitments/

$g$ "Discretionary price-based mechanisms, such as a carbon price floor and a reserve, with an explicit carbon price objective, would alter the very nature of the current EU ETS being a quantity-based market instrument. They require governance arrangements, including a process to decide on the level of the price floor or the levels that would activate the reserve. This carries a downside in that the carbon price may become primarily a product of administrative and political decisions (or expectations about them), rather than a result of the interplay of market supply and demand" ${ }^{\prime 4}$, as if the supply of allowances was not a product of political decisions, just as a carbon price would be.

${ }^{\mathrm{h}}$ The same argument can be applied to the UK "carbon price floor", a tax on UK emissions covered by the ETS, if the allowance price falls below a certain level.

'For information on carbon markets, see http://www.edf.org/climate/worlds-carbonmarkets

\section{References}

${ }^{1}$ CEOEurope. EU ETS Myth Busting: Why It Can't Be Reformed and Shouldn't Be Replicated. CEO Europe, 2013.

${ }^{2}$ Hahn, R.W. "Economic Prescriptions for Environmental Problems: How the Patient Followed the Doctor's Orders." Journal of Economic Perspectives 3, no. 1 (1989): 95-114.

${ }^{3}$ Laing, Timothy, Misato Sato, Michael Grubb, and Claudia Comberti. "The Effects and SideEffects of the EU Emissions Trading Scheme: The Effects and Side-Effects of the EUETS." Wiley Interdisciplinary Reviews: Climate Change 5, no. 4 (July 2014): 509-19. doi:10.1002/wcc.283.

${ }^{4}$ Ellerman, A. Denny, and Barbara K. Buchner. "Over-Allocation or Abatement? A Preliminary Analysis of the EU ETS Based on the 2005-06 Emissions Data." Environmental and Resource Economics 41, no. 2 (2008): 267-87. doi:10.1007/s10640-008-9191-2.

${ }^{5}$ Anderson, Barry, and Corrado Di Maria. "Abatement and Allocation in the Pilot Phase of the EU ETS." Environmental and Resource Economics 48, no. 1 (2011): 83-103.

${ }^{6}$ Delarue, E., K. Voorspools, and W. D'haeseleer. "Fuel Switching in the Electricity Sector under the EU ETS: Review and Prospective." Journal of Energy Engineering 134, no. 2 (2008): 40-46. doi:10.1061/(ASCE)0733-9402(2008)134:2(40).

${ }^{7}$ Zachman, Georg, Jan Abrell, and Anta Ndoye Faye. Assessing the Impact of the EU ETS Using Firm Level Data. Bruegel Working Paper, 2011. 
${ }^{8}$ Egenhofer, Christian, Monica Alessi, Anton Georgiev, and Noriko Fujiwara. The EU Emissions Trading System and Climate Policy Towards 2050: Real Incentives to Reduce Emissions and Drive Innovation? SSRN Scholarly Paper. Rochester, NY: Social Science Research Network, January 12, 2011. http://papers.ssrn.com/abstract=1756736.

${ }^{9}$ Newell, Richard G., William A. Pizer, and Daniel Raimi. "Carbon Markets 15 Years after Kyoto: Lessons Learned, New Challenges." The Journal of Economic Perspectives 27, no. 1 (2013): 123-46. doi:10.1257/jep.27.1.123.

${ }^{10}$ Stephan, Nicolas, Valentin Bellassen, and Emilie Alberola. Utilisation Des Crédits Kyoto Par Les Industriels Européens: D'un Marché Efficace À L'éclatement D'une Bulle (in French). Etude Climat. CDC Climat Recherche, 2014.

${ }^{11}$ Montgomery, W. "Markets in Licences and Efficient Pollution Control Programs." Journal of Economic Theory, 1972, 5 edition.

${ }^{12}$ Zhang, Junjie, and Can Wang. "Co-Benefits and Additionality of the Clean Development Mechanism: An Empirical Analysis." Journal of Environmental Economics and Management 62, no. 2 (September 2011): 140-54. doi:10.1016/j.jeem.2011.03.003.

${ }^{13}$ Schneider, L. "Assessing the Additionality of CDM Projects: Practical Experiences and Lessons Learned." Climate Policy 9, no. 3 (2009): 242-54. doi:10.3763/cpol.2008.0533.

${ }^{14}$ Branger, Frédéric, and Philippe Quirion. "Climate Policy and the 'carbon Haven' Effect." Wiley Interdisciplinary Reviews: Climate Change 5, no. 1 (2014): 53-71. doi:10.1002/wcc.245.

${ }^{15}$ Böhringer, Christoph, Edward J. Balistreri, and Thomas F. Rutherford. "The Role of Border Carbon Adjustment in Unilateral Climate Policy: Overview of an Energy Modeling Forum Study (EMF 29)." Energy Economics 34 (December 2012): S97-S110. doi:10.1016/j.eneco.2012.10.003.

${ }^{16}$ Branger, Frédéric, and Philippe Quirion. "Would Border Carbon Adjustments Prevent Carbon Leakage and Heavy Industry Competitiveness Losses? Insights from a Meta-Analysis of Recent Economic Studies." Ecological Economics 99 (March 2014): 29-39. doi:10.1016/j.ecolecon.2013.12.010.

${ }^{17}$ Reinaud, Julia. Issues behind Competitiveness and Carbon Leakage. Focus on Heavy Industrys. IEA Information Paper. OECD/IEA Paris: International Energy Agency, 2008.

${ }^{18}$ Lacombe, R. Economic Impact of the European Union Emissions Trading System : Evidence from the Refining Sector. MIT Master thesis, 2008.

${ }^{19}$ Sartor, Oliver. Carbon Leakage in the Primary Aluminium Sector: What Evidence after 6.5 Years of the EU ETS? SSRN Scholarly Paper. Rochester, NY: Social Science Research Network, 2013. http://papers.ssrn.com/abstract=2205516. 
${ }^{20}$ Branger, Frédéric, Philippe Quirion, and Julien Chevallier. Carbon Leakage and Competitiveness of Cement and Steel Industries under the EU ETS: Much Ado about Nothing. Working Paper CIRED, 2013.

${ }^{21}$ Ellerman, Denny, Franck Convery, and Christian de Perthuis. Pricing Carbon : The European Union Emissions Trading Scheme. Cambridge University Press. Cambridge, UK, 2010.

${ }^{22}$ Hourcade, Jean-Charles, Damien Demailly, Karsten Neuhoff, and Misato Sato.

Differentiation and Dynamics of EU ETS Competitiveness Impacts. Cambridge, UK: Climate Strategies, 2007.

${ }^{23}$ Juergens, Ingmar, Jesús Barreiro-Hurlé, and Alexander Vasa. "Identifying Carbon Leakage Sectors in the EU ETS and Implications of Results." Climate Policy 13, no. 1 (2013): 89-109. doi:10.1080/14693062.2011.649590.

${ }^{24}$ Dechezleprêtre, Antoine, Matthieu Glachant, and Yann Ménière. "The Clean Development Mechanism and the International Diffusion of Technologies: An Empirical Study." Energy Policy 36, no. 4 (2008): 1273-83. doi:10.1016/j.enpol.2007.12.009.

${ }^{25}$ Gerlagh, Reyer, and Onno Kuik. "Spill or Leak? Carbon Leakage with International Technology Spillovers: A CGE Analysis." Energy Economics 45 (September 2014): 381-88. doi:10.1016/j.eneco.2014.07.017.

${ }^{26}$ Porter, Michael E., and Claas van der Linde. "Toward a New Conception of the Environment-Competitiveness Relationship." The Journal of Economic Perspectives 9, no. 4 (1995): 97-118. doi:10.2307/2138392.

${ }^{27}$ Branger, Frédéric, and Philippe Quirion. Reaping the Carbon Rent: Abatement and Overallocation Profits in the European Cement Industry, Insights from an LMDI Decomposition Analysis (forthcoming), 2014.

${ }^{28}$ Quirion, Philippe. “Competitiveness and Leakage." In Climate Change Policies - Global Challenges and Future Prospects, 77-94. University of Vigo, Spain: Emilio Cerdá, 2010.

${ }^{29}$ Lecourt, Stephan, Clément Pallière, and Oliver Sartor. The Impact of EmissionsPerformance Benchmarking on Free Allocations in EU ETS Phase 3. EUI Working Paper, 2013.

${ }^{30}$ De Bruyn, S., Dagmar Nelissen, and Marnix Koopman. Carbon Leakage and the Future of Carbon Markets in Europe - Impacts of Recent Developments in the EU ETS on the List of Sectors Deemed to Be Exposed to Carbon Leakage. CE Delft, 2013.

${ }^{31}$ Sijm, Jos, Karsten Neuhoff, and Yihsu Chen. "CO2 Cost Pass-through and Windfall Profits in the Power Sector." Climate Policy 6, no. 1 (2006): 49-72.

doi:10.1080/14693062.2006.9685588. 
32 Gow, David. "Power Tool." The Guardian, May 17, 2006, sec. Environment. http://www.guardian.co.uk/environment/2006/may/17/europeanunion.climatechange.

${ }^{33}$ Bovenberg, A. Lans, and Lawrence H. Goulder. Neutralizing the Adverse Industry Impacts of $\mathrm{CO} 2$ Abatement Policies: What Does It Cost? NBER Working Paper. National Bureau of Economic Research, Inc, 2000. http://ideas.repec.org/p/nbr/nberwo/7654.html.

${ }^{34}$ Burtraw, Dallas, Karen Palmer, Ranjit Bharvirkar, and Anthony Paul. The Effect of Allowance Allocation on the Cost of Carbon Emission Trading. Discussion Papers. Resources For the Future, August 2001. http://ideas.repec.org/p/rff/dpaper/dp-01-30-.html.

${ }^{35}$ Lise, Wietze, Jos Sijm, and Benjamin F. Hobbs. "The Impact of the EU ETS on Prices, Profits and Emissions in the Power Sector: Simulation Results with the COMPETES EU20 Model." Environmental and Resource Economics 47, no. 1 (April 9, 2010): 23-44. doi:10.1007/s10640-010-9362-9.

${ }^{36}$ De Bruyn, S., A. Markowska, F. de Jong, and M. Bles. Does the Energy Intensive Industry Obtain Windfall Profits through the EU ETS? An Econometric Analysis for Products from the Refineries, Iron and Steel and Chemical Sectors. CE Delft, 2010.

${ }^{37}$ Alexeeva-Talebi, Victoria. "Cost Pass-through of the EU Emissions Allowances: Examining the European Petroleum Markets." Energy Economics 33, Supplement 1 (décembre 2011): S75-S83. doi:10.1016/j.eneco.2011.07.029.

${ }^{38}$ Oberndorfer, U, V Alexeeva-Talebi, and Andreas Löschel. Understanding the Competitiveness Implications of Future Phases of EU ETS on the Industrial Sectors. Discussion Paper. ZEW, 2010.

${ }^{39}$ Europol. Further Investigations into VAT Fraud Linked to the Carbon Emissions Trading System. Europol, 2010. https://www.europol.europa.eu/content/press/furtherinvestigations-vat-fraud-linked-carbon-emissions-trading-system-641.

${ }^{40}$ Interpol. Guide to Carbon Trading Crime. Interpol, 2013.

${ }^{41}$ Pizer, William A. "The Optimal Choice of Climate Change Policy in the Presence of Uncertainty." Resource and Energy Economics 21, no. 3-4 (August 1999): 255-87. doi:10.1016/S0928-7655(99)00005-6.

${ }^{42}$ Ellerman, Denny, and Franck Convery. "Addressing Criticisms of the European Union Emissions Trading Scheme." EAERE Newsletter Autumn 2011, 2011.

${ }^{43}$ Lecuyer, Oskar, and Philippe Quirion. "Can Uncertainty Justify Overlapping Policy Instruments to Mitigate Emissions?" Ecological Economics 93 (September 2013): 177-91. doi:10.1016/j.ecolecon.2013.05.009. 
${ }^{44}$ EuropeanCommission. The State of the European Carbon Market in 2012. European Commission, 2012.

${ }^{45}$ Taschini, Luca. Options for Structural Measures to Improve the European Union Emissions Trading System: Response to a European Commission Consultation. Policy paper. Grantham Research Institute, 2013.

${ }^{46}$ Trotignon, R., Frédéric Gonand, and C. De Perthuis. EU ETS Reform in the Climate-Energy Package 2030: First Lessons from the ZEPHYR Model. Policy Brief. Climate Economics Chair, 2014.

${ }^{47}$ Richstein, Jörn, Emile Chappin, and Laurens de Vries. "The Stability Reserve in EU Carbon Emission Trading: Doest It Deliver What It Promises?." New York, 2014.

${ }^{48}$ Frankhauser, Samuel, Cameron Hepburn, and Jisung Park. Combining Multiple Climate Policy Instruments: How Not to Do It, n.d.

${ }^{49}$ Böhringer, Christoph, and Knut Einar Rosendahl. "Green Promotes the Dirtiest: On the Interaction between Black and Green Quotas in Energy Markets." Journal of Regulatory Economics 37, no. 3 (June 1, 2010): 316-25. doi:10.1007/s11149-010-9116-1.

50 Jaffe, Adam B., Richard G. Newell, and Robert N. Stavins. "A Tale of Two Market Failures: Technology and Environmental Policy." Ecological Economics 54, no. 2-3 (2005): 164-74. doi:doi: 10.1016/j.ecolecon.2004.12.027.

${ }^{51}$ Fischer, Carolyn, lan W. H. Parry, and William A. Pizer. "Instrument Choice for Environmental Protection When Technological Innovation Is Endogenous." Journal of Environmental Economics and Management 45, no. 3 (2003): 523 - 545. doi:DOI: 10.1016/S0095-0696(03)00002-0.

52 Popp, David. "Induced Innovation and Energy Prices." The American Economic Review 92, no. 1 (2002): 160-80. doi:10.2307/3083326.

${ }^{53}$ Fischer, C. "Emissions Pricing, Spillovers, and Public Investment in Environmentally Friendly Technologies." Energy Economics 30, no. 2 (2008): 487-502.

54 Jaffe, A. B., R. G. Newell, and R. N. Stavins. "Economics of Energy Efficiency." Encyclopedia of Energy 2 (2004): 79-90.

${ }^{55}$ Gillingham, Kenneth, Matthew Harding, and David Rapson. "Split Incentives in Residential Energy Consumption." The Energy Journal 0, no. Number 2 (2012). http://ideas.repec.org/a/aen/journl/33-2-03.html.

${ }^{56}$ Sijm, Jos. "The Interaction between the EU Emissions Trading Scheme and National Energy Policies." Climate Policy 5, no. 1 (2005): 79-96. doi:10.1080/14693062.2005.9685542. 
${ }^{57}$ Vogt-Schilb, Adrien, Guy Meunier, and Stéphane Hallegatte. Should Marginal Abatement Costs Be Different across Sectors? The Effect of Green Capital Accumulation. Policy research paper. World Bank, 2013.

${ }^{58}$ Lecuyer, Oskar, and Adrien Vogt-Schilb. Assessing and Ordering Investments in Polluting Fossil-Fueled and Zero-Carbon Capital. Working Paper. CIRED, 2013.

Related articles

\begin{tabular}{|l|l|}
\hline $\begin{array}{l}\text { WIREs ClimChange 2013, } \\
\text { 5:509-519. } \\
\text { doi:10.1002/wcc.283 }\end{array}$ & $\begin{array}{l}\text { "The Effects and Side-Effects of the EU Emissions Trading } \\
\text { Scheme: The Effects and Side-Effects of the EUETS" by } \\
\text { Timothy Laing, Misato Sato, Michael Grubb and Claudia } \\
\text { Comberti }\end{array}$ \\
\hline $\begin{array}{l}\text { WIREs ClimChange 2013, } \\
\text { 4:107-119. } \\
\text { doi:10.1002/wcc.208 }\end{array}$ & "Carbon markets: a historical overview" by Raphael Calel \\
\hline $\begin{array}{l}\text { WIREs ClimChang } 20101 \\
\text { 144-153 } \\
\text { doi: } 10.1002 / \text { wcc.17 }\end{array}$ & "The EU Emissions Trading Scheme" by lan Bailey \\
\hline
\end{tabular}

